\title{
Note on the Action of Strychnine upon some Somatic Cells.
}

\author{
BY \\ HELEN P. KEMP, \\ Royal College of Science, London.
}

HE question of the nature of the alkaloids and of their action upon
the living cell is one bearing closely upon that of absorption in general. Recognition of the fundamental character of the latter process, as a biological phenomenon of the first importance, has led to a considerable activity in this particular field of investigation ; marked by the appearance, during the last three decades, of various accounts of the action of certain of the alkaloids upon different types of cell. There has been, however, so little co-ordination of work that not only is the advance made along this line relatively small, but the results also in some cases are ambiguous. The ambiguity appears to be largely due to the fact that similar methods have been used and similar phenomena studied with different ends in view, and cross-references made without a sufficient indication of the dissimilarity of the latter.

In I887 Oscar and Richard Hertwig (3) published the results of a series of experiments on the action upon Echinoderm eggs of certain alkaloidal poisons, among others quinine, chloral, nicotine, and strychnine. They immersed the eggs in solutions of varied strength $(0.005 \%-0.1 \%)$ and for varied lengths of time (IO mins. -3 hrs.) and then placed them in sea-water containing spermatozoa. As an indicator of the action of the various alkaloids, and as a standard of comparison between them, they chose the condition of polyspermy in the egg, this being dependent upon a modification of the latter under the influence of the poisons, by which it is rendered permeable to more than one spermatozoon. They used eggs at three distinct physiological stages of development, (I) non-maturated, (2) maturated but unfertilized, (3) fertilized; and obtained differences of result according to the stage chosen. Thus class (I) was found to be extremely sensitive to the modification indicated by polyspermy, such eggs after treatment with the poison being filled with spermatozoa, class (2) to be less sensitive, and class (3) almost impervious, the eggs developing, as far as could be seen, normally up to the pluteus stage, subsequent to their

[Annals of Botany, Vol. XXV. No. C. October, r911.] 
immersion in strychnine. These differences are significant in a comparison of the results obtained with eggs, with those obtained with somatic cells.

The authors classed the alkaloids roughly according to the nature of their action, and stated that whereas quinine and chloral seemed to diminish the contractility of the protoplasm, destroyed the achromatic fibres, and seriously inhibited karyokinesis and the subsequent division of the cell, strychnine (and nicotine) on the contrary greatly increased the contractility of the protoplasm, and exercised no injurious effect upon either the achromatic structures or the processes of karyokinesis and cell-division. They further showed that with a stronger solution of strychnine $(0.01 \%-0.25 \%)$ and prolonged immersion (2-3 hrs.) further development of the egg was arrested, and regressive metamorphosis ensued, terminated by fragmentation. They concluded that strychnine (as also nicotine and morphine) did not affect karyokinesis in any specific way, but only, if used in a sufficiently strong solution, by inducing a general inhibition of the metabolic processes, resulting, if severe, in complete degeneration of the egg.

The occurrence of tripolar and quadripolar division figures after treatment with chloral or quinine, i. e. the class of alkaloids opposed to that containing strychnine, is noted by the authors as being perhaps due to the condition of polyspermy, rather than directly to the action of the drugs themselves. This introduction of a confusing factor is certainly a serious disadvantage attaching to the use of polyspermy as an indicator of the action of the poisons. But it appears probable that the figures in question arise as a direct result of the drugs, rather than of the condition of polyspermy, since in 1893 Galeotti (2) described similar irregular mitoses, occurring in regenerating epithelial cells of the salamander on treatment with quinine and certain other alkaloids; and mitoses of the same character also occur in the somatic tissue of plants which have been subjected to the action of chloral (Němec (8), Kemp (5)).

In I $896 \mathrm{R}$. Hertwig (4) published the results of further experiments with strychnine upon Echinoderm eggs. He showed that by treating them with solutions of different strengths, the unfertilized eggs could be induced to form spindles of different degrees of completion; also that on pushing the process further and using one of the stronger percentages (over $0.1 \%$ ) for a longer time $(3-5 \mathrm{hrs}$.), inhibition of the artificially induced activity took place, followed by degeneration of the egg. He noted that the connexion between the mitosis of the nucleus and division of the cell was uncertain, and that the former was frequently followed by a series of abnormal imperfect divisions, giving rise to various multinucleate or anucleate conditions. He also noted that fragmentation of the cell might take place apart from any true mitosis of the nucleus, and that such fragmentation was preceded by dissolution of the nuclear membrane and scattering of the chromosomes throughout the cytoplasm to form swollen vesicular bodies. 
He concluded that the effect of the strychnine was confined to causing the onset of an activity of division latent in the unfertilized egg-cell, and that the above abnormal figures were of too obscure an origin to throw light upon the process of normal division and were consequently not worth following out, particularly as they generally heralded degeneration of the cell.

In I900 Morgan (7) published the results of experiments with strychnine on the eggs of Arbacia. The emphasis of the paper, however, is chiefly upon the occurrence of cytoplasmic striation under the influence of the poison, and although the author quotes Hertwig at length, he contributes no fresh data concerning the abnormal nuclear figures described by the latter.

In I 902 Wasilieff (10) brought out a paper on the action of strychnine and certain other alkaloids upon the eggs of Strongylocentrotus lividus, but here again the writer is chiefly concerned with another point than that of the occurrence of abnormal divisions, namely, with the origin of the centrosome. He states, however, that spindles of peculiar shape arise after treatment with strychnine, and notes Hertwig's observation of subsequent irregular divisions.

Hertwig's paper of 1896 was quoted again in 1903 by Delage (1) in an account of the behaviour of the eggs of Asterias on exposure to carbon dioxide. Delage stated that the gas was capable of exciting to division approximately $100 \%$ of eggs, provided the latter were in a state of incipient activity, i. e. about to form polar bodies, or having just done so. He noted that full development was never reached, but did not describe any abnormal divisions occurring during the retrogressive changes in the eggs.

From the year 1899 until the present time, investigations have been carried by Loeb (6) far along the line indicated by Hertwig's discovery of artificial parthenogenesis. Loeb treated the problem less from the point of view of abnormalities arising under particular conditions, than from the side of its wider interest, that depending on the nature of absorption in general ; though he can perhaps hardly be said to have studied absorption per se so effectively as the results of absorption. He performed upon various kinds of egg extensive and detailed experiments with the salts of magnesium, potassium, sodium, and calcium, and also with some members of the fattyacid series, and was successful in inducing development to an advanced stage. In 1906 he suggested that the direct effect of the sperm in normal development, and of the methods of artificial parthenogenesis, was the starting of a definite chemical process; and pointed out in support of this view that the process of segmentation is as entirely regular in parthenogenetic development as in that of fertilized eggs.

The present note gives briefly the data obtained from some experiments with strychnine, undertaken with a view to examining the mitoses described by Hertwig in 1896 . It has been necessary to leave the work unfinished, 
and the results are consequently incomplete, but their publication in that state seems justified by the fact that, as far as they go, they are of a nature sufficiently definite to afford a basis for possible further advance. Roots of Pea and Bean seedlings were chosen for experiment as affording a readily procurable supply of young tissue in a state of activity. Incidentally the use of somatic instead of reproductive tissue has this advantage-that it precludes any possible confusion between the spindle formation of the two rapidly successive polar-body divisions of the unmaturated egg-cell, and the spindles of irregular shape said to arise under the influence of the poisons. The seedlings were grown and manipulated during experiment in the following way. They were started in sawdust, and on their roots attaining a length of some inches were placed with the tips of the tap-roots in the poison; on removal from the latter they were replanted in sawdust, after washing. Several series of experiments were worked out. In the first two or three strychnine hydrochloride, but subsequently also the sulphate, was used, in various percentages and for various lengths of time $(0.0001 \%, 0.001 \%$, $0.01 \%, 0.1 \%, 0.25 \%$, and $0.5 \%$ for $10,15,20$ mins., half an hour, and I hour). Fixation of the roots, either directly after treatment with strychnine or at different points of further growth, failed to reveal any of the abnormal mitoses in question. The only visible effect of the strychnine was a shrinkage in the cytoplasm of the outer cell-rows, varying roughly in amount with the strength of the solution used, and an apparent slight increase of karyokinetic activity in the more central layers of the tissue, the latter point, however, being difficult of exact proof. The mitoses were normal in appearance, with strongly marked achromatic fibres and clearly divided groups of chromosomes.

It seemed possible from these results that the poison either had not entered the roots at all, or had not penetrated beyond the outer layers of cells, and on the indication of Loeb's (6) work with alkalies upon eggs, and of Overton's (9) observations on narcosis in tadpoles, a modification was made in the experiments, and the solutions of strychnine rendered slightly alkaline with sodium carbonate or hydrate. In an alkaline solution, however, some of the strychnine base was thrown down, and it was doubtful what percentage of it remained in solution. Microscopical examination showed also no features essentially different from those seen in the earlier experiments, but a more severe shrinkage of the cytoplasm, a condition seen also in the control experiments with tap water containing the same proportions of the alkali as were used in the strychnine solutions, i.e. $\frac{N}{10}, \frac{N}{20}$, and $\frac{N}{40}$. A wide range of percentages and of periods of immersion was used (0.00I, 0.01 , $0.1,0.25$, and $0.5 \%$ of strychnine, in solutions of sodium carbonate or hydrate from $\frac{N}{10}, \frac{N}{20}$ to $\frac{N}{40}$, for 10, 15, 20 mins., half an hour, I hour), but no result was obtained beyond distortion of the nuclei and shrinkage of the 
cytoplasm after treatment with the stronger solutions. The experiment was then tried of first placing the roots in the above percentages of strychnine for I 5 mins. or half an hour, and then transferring them to the alkaline strychnine solution. This was done on the supposition that it might be essential for the poison to secure a hold upon the tissue previous to the dissociating action of the alkali. Again, however, the results were negative, and no physiological reaction of the tissue was observable other than the apparent increase of karyokinetic activity noted above. This method was therefore abandoned and attention concentrated upon ascertaining whether the poison had penetrated the roots.

It was considered that whereas the experiments described above dealt essentially with static conditions, the introduction into the latter of a dynamic factor, such as transpiration, might yield more decisive results, the poison being sucked up forcibly through the roots. With this end in view water-cultures of the Pea were made, and on sufficient growth of stem and leaves to ensure the occurrence of transpiration, the intact plants were placed with their roots in solutions of strychnine ranging in percentage from 0.5 to 0.05 and $0.005 \%$. On removal of the plants from the poison after various periods of immersion $(18,20,48 \mathrm{hrs}$.), the root-tips were fixed, either at once or after further cultivation in a salt solution, for microscopical examination; the stems and leaves were extracted for strychnine. In fixing the plants in the poison care was taken to immerse the roots only to a point which left several inches below the hypocotyl exposed above the surface of the solution. The hypocotyl, cotyledons, and a couple of inches of root and stem below and above the latter, were coated with vaseline. The hypocotyl was then wrapped in soft asbestos and the plant inserted, by removal of a wedge, into the cork of the culture bottle as during cultivation. When the experiments were performed in an open glass, the mouth of the latter was covered with strong paper or thin macintosh. By this method the possibility of capillary movement of the solution up the outside of the roots and over the stem was obviated, and any strychnine found in the stems and leaves must therefore have reached the latter through the vascular tissue of the roots, after penetrating the outer cells.

The extractions were made as follows: The plant was cut off above the vaselined area of the stem, chopped up, and extracted with alcohol at about $30^{\circ} \mathrm{C}$. for several hours. The extract was then filtered off, and evaporated to dryness; the residue picked up with water, neutralized, and shaken with ether after again filtering. The ether was evaporated and the small residue which remained tested for the presence of strychnine. The chemical tests used for detection of the latter were :-

I. Mandeline's reagent (a solution of vanadium chloride in strong sulphuric acid), giving a violet colour in the presence of strychnine, turning to cherry pink. 
2. Sulphuric acid and potassium bichromate, giving a deep violet in the presence of strychnine.

The residue was also examined for crystals and for the intensely bitter taste characteristic of strychnine.

The result of the tests was as follows. The presence of strychnine was demonstrated in the stems and leaves of the plants examined, in amounts varying very roughly with the strength of the original solution. Thus, while only to be detected by bitterness to the taste and by faint, though distinct colour reactions, in the plants treated with a solution containing $0.005 \%$ of strychnine, in those which had been subjected to the action of a $0.5 \%$ solution the base was obtained in a crystalline form from the ether residue and the colour reactions were vivid.

The absorption of strychnine through the roots of the above plants being proved by the appearance of the poison in their stems, a microscopical examination was made of the root-tips fixed in parallel to the stem extractions. The periods of immersion in these transpiration experiments having been somewhat prolonged, in order to allow ample time for the rise of the poison in the stem, the effect observed microscopically in the roots was naturally severe, but the general results were similar to those of the earlier experiments with strychnine. In those which had been treated with the stronger percentages the nuclei were shrivelled, diffusely stained, and apparently dead; and also in the roots fixed immediately after removal from the poison, whether of weaker or stronger percentage, they were seen to be in a completely inactive and apparently pathological condition. In the roots which had been subjected to the $0.5 \%$ solution no recovery was observed, but where weaker solutions had been used (0.05 and $0.005 \%)$ there was a gradual return of activity, after the plant had been replaced in its culture solution for a few days, the nuclei staining more clearly and here and there undergoing mitosis. Such mitoses were to all appearance normal and none of the irregular figures described by Hertwig were found.

It seems possible that the difference between the results obtained in these experiments with somatic cells, and those obtained by Hertwig with eggs, may be due to an essential difference in the physiological character of the two kinds of tissue. It was noted above that $\mathrm{O}$. and R. Hertwig, in working with Echinoderm eggs at three distinct stages of development, obtained a characteristic type of response at each stage. Again, it has been found that between two kinds of egg--such as those of Asterias and Strongylocentrotus - there is a considerable difference of sensitivity to external stimuli; those of the former being more easily excited to parthenogenetic division than are the latter. Further, it has been shown that in many hybrids, whereas the nuclei of the sexual cells show remarkable irregularities in their division figures, those of the somatic tissue are perfectly 
normal. It is conceivable that between the animal egg and the plant-cell a similar physiological difference may be the cause of the difficulty in inducing, in the plant, types of mitosis which occur readily in the egg-cell of the animal.

\section{SumMary AND CONCLUSION.}

Somatic tissues of the Pea (Pisum Sativum) and Bean (Vicia Faba) were treated with the sulphate and hydrochloride of strychnine with a view to inducing the occurrence of the abnormal divisions described by Hertwig in 1896 . No such figures were found.

In order to promote dissociation of the salts, and thereby possibly their absorption by the roots, the strychnine solutions were made slightly alkaline with sodium carbonate or hydrate. These alkaline solutions had no greater effect than those of natural reaction. The penetration of the poison into the tissue therefore appeared doubtful.

A series of experiments with water-culture Peas was carried out with two objects: (I) in order to utilize the factor of transpiration, and so promote absorption of the strychnine ; $(2)$ in order to make extractions of the stems and leaves for strychnine, and so obtain a positive datum as to the entry of the poison into the root-cells.

The presence of strychnine in the stems was demonstrated by this method, and correlatively its absorption by the roots. Microscopical examination of the latter, however, yielded results similar to those obtained in the earlier experiments, and no abnormal divisions were found.

These results indicate that strychnine exercises no specific effect upon the tissues used in the above experiments, exciting in them no definite physiological response, but only, if used in sufficient strength, producing a general disturbance of metabolism, from which recovery is doubtful and which generally precedes degeneration.

In conclusion, I take the opportunity of thanking Professor J. Bretland Farmer, F.R.S., for his advice and direction in this investigation; and also Dr. M. A. Whiteley for most kindly giving me detailed help in making the necessary chemical examinations.

\section{BIBLIOGRAPHY.}

1. Delage, T. H.: Nouvelles recherches sur la parthénogenèse expérimentale chez Asterias glacialis. Archives de Zoologie Expérimentale, $1902,3^{\mathrm{me}}$ série, pp. 214-35.

2. GaLeOtTi, G. : Ueber experimentelle Erzeugung von Unregelmässigkeiten des karyokinetischen Processes. Beiträge z. pathologischen Anat. u. z. allgemeinen Pathologie, 1893, pp. 288-314.

3. Hertwig, O. and R. : Ueber den Befruchtungs- und Teilungsvorgang des tierischen Eies unter dem Einfluss äusserer Agenten. Jena, I887. 
1076 Kemp.- Note on the Action of Strychnine upon Somatic Cells.

4. Hertwig, R. : Ueber die Entwickelung des unbefruchteten Seeigeleies. Festschrift für Gegenbauer, Bd. ii, 1896, pp. 23-86, Leipzig.

5. Kemp, H. P.: On the Question of the Occurrence of 'Heterotypical Reduction' in Somatic Cells. Annals of Bot., vol. xxiv, No. xcvi, Oct., 1910.

6. Loeb, J.: The Dynamics of Living Matter. Columbia University Press, 1906.

7. Morgan, T. H. : Further Studies on the Action of Salt Solutions and of other Agents on the Eggs of Arbacia. Archiv f. Ent.-Mech., x, 1900, pp. 489-524.

8. Nemec, B.: Ueber die Einwirkung des Chloralhydrats auf die Kern- und Zellteilung. Jahrb. wiss. Bot., xxxix, I904.

9. OVerton, E. : Studien über d. Narkose. Jena, I9or.

10. Wasilie ff, A.: Ueber künstliche Parthenogenesis des Seeigeleies. Biolog. Centralblo, xxii, I902. 


\section{$2 \mathrm{BHL}$ Biodiversity Heritage Library}

Kemp, Helen P. 1911. "Note on the action of strychnine upon some somatic cells." Annals of botany 25, 1069-1076.

https://doi.org/10.1093/oxfordjournals.aob.a089363.

View This Item Online: https://www.biodiversitylibrary.org/item/239487

DOI: https://doi.org/10.1093/oxfordjournals.aob.a089363

Permalink: https://www.biodiversitylibrary.org/partpdf/319878

\section{Holding Institution}

Smithsonian Libraries

\section{Sponsored by}

Biodiversity Heritage Library

\section{Copyright \& Reuse}

Copyright Status: Not in copyright. The BHL knows of no copyright restrictions on this item.

This document was created from content at the Biodiversity Heritage Library, the world's largest open access digital library for biodiversity literature and archives. Visit BHL at https://www.biodiversitylibrary.org. 